\title{
Unusual subtypes of prostate cancer
}

\author{
David J Grignon \\ Department of Pathology, Harper University Hospital and Wayne State University School of Medicine, \\ Detroit, MI, USA
}

\begin{abstract}
The vast majority of prostatic tumors developing in adult males are adenocarcinomas. For the most part, variations in histology have not received specific designations and, from a practical approach, have had any specific prognostic implications handled through application of the Gleason grading system. Nonetheless, some of the adenocarcinoma variants have specific clinical features and differential diagnoses. Furthermore, there has been some controversy regarding the appropriate application of the Gleason grading scheme in these tumors. In addition, there are carcinomas that are in fact not adenocarcinomas and that should be kept as distinct entities. In this paper, the histologic variants of adenocarcinoma are reviewed with emphasis on clinicopathologic features and the clinical relevance of these subtypes. Other carcinomas that occur in the prostate gland are also discussed again with a focus on the clinicopathologic characteristics.

Modern Pathology (2004) 17, 316-327, advance online publication, 13 February 2004; doi:10.1038/modpathol.3800052
\end{abstract}

Keywords: prostate gland; variants; adenocarcinoma; basaloid carcinoma; small-cell carcinoma; urothelial carcinoma; squamous cell carcinoma

As reflected in the Gleason scoring system, the histologic patterns that prostatic adenocarcinoma can assume are extensive (Table 1 ). ${ }^{1}$ While some patterns such as mucinous and signet ring types are not specifically dealt with in the Gleason system, others such as the ductal ('endometrioid') type are. ${ }^{2}$ For the most part, these various architectural patterns have no specific clinical-pathologic features and are of greatest importance to the pathologist alone. Knowledge of the appropriate grading of the patterns with assignment of the correct Gleason score is, however, of great clinical significance (Table 2). ${ }^{3}$ The following sections will highlight the important clinicopathologic features of the major histologic subtypes of adenocarcinoma and other carcinomas that occur in the prostate gland.

\section{Prostatic ductal adenocarcinoma}

This tumor accounts for $<1 \%$ of prostatic adenocarcinomas (as a dominant pattern) and has been referred to under a number of different names including 'endometrioid' and 'papillary' carcinoma. ${ }^{4-12}$ It can be identified as a lesser pattern in up to $3 \%$ of cases. Initially, these tumors were believed to be of endometrial origin arising in the verumon-

Correspondence: Dr DJ Grignon, MD, Department of Pathology, Harper University Hospital, 3990 John R, Detroit, MI 48201, USA. E-mail: dgrignon@med.wayne.edu

Received 28 October 2003; accepted 19 November 2003; published online 13 February 2004 tanum, a müllerian remnant; ${ }^{4,5}$ however, it is now recognized that these are of prostatic epithelial origin. ${ }^{6-12}$ The concept of ductal adenocarcinoma as a specific entity has been challenged, most recently by Bock and Bostwick. ${ }^{13}$ In a study utilizing $\mathrm{LOH}$ analysis of 12 polymorphic microsatellite markers, frequently lost in prostate cancer, Dawkins et al. ${ }^{14}$ reported LOH in none of the Gleason grade 3 tumors studied, $9 \%$ of high-grade prostatic intraepithelial neoplasia (HGPIN) lesions, 29\% of Gleason grade 4 cancers and $60 \%$ of ductal adenocarcinomas, suggesting that these are in fact a different lesion.

Clinically, ductal adenocarcinoma often involves the central ducts of the gland and may present as an exophytic papillary lesion in the prostatic urethra. ${ }^{15}$ For this reason, they are often seen in transurethral resection (TUR) specimens and at radical prostatectomy (RP), and are less often found in needle biopsies. Obstructive symptoms and hematuria are common. The prostate gland is usually enlarged and nodular. There have been varying reports concerning serum prostate-specific antigen (PSA) and prostatic acid phosphatase (PAP) measurements in cases with a predominant ductal pattern with some indicating a lower level than might otherwise be expected. These tumors do metastasize to bone. Prognosis is probably similar stage for stage and grade for grade (see discussion of grade below) with acinar carcinomas, although some have reported better and others a worse prognosis for this pattern. Overall, the tumors do appear to have a worse 
Table 1 Variants of prostatic adenocarcinoma

Ductal (endometrioid) adenocarcinoma

Mucinous (colloid) carcinoma

Signet ring cell carcinoma

Pseudohyperplastic carcinoma ${ }^{a}$

Adenocarcinoma with atrophic features ${ }^{\mathrm{a}}$

Foamy gland carcinoma

Adenocarcinoma with carcinoid-like morphology

Adenocarcinoma with Paneth-like cells ${ }^{\mathrm{a}}$

${ }^{\mathrm{a}}$ These are not generally included as specific variants of adenocarcinoma and are not discussed in this review.

Table 2 Gleason grading of prostate carcinoma subtypes ${ }^{\mathrm{a}}$

\begin{tabular}{|c|c|}
\hline Histologic type & Gleason grade \\
\hline Prostatic ductal adenocarcinoma & $\begin{array}{l}\text { Grade } 4,5 \text { with necrosis, } \\
\text { some } 3\end{array}$ \\
\hline Mucinous (colloid) adenocarcinoma & Grade 4 \\
\hline Signet ring cell carcinoma & Grade 5 \\
\hline $\begin{array}{l}\text { Adenosquamous and squamous cell } \\
\text { carcinoma }\end{array}$ & Not graded \\
\hline $\begin{array}{l}\text { Basaloid and adenoid cystic } \\
\text { carcinoma }\end{array}$ & Not graded \\
\hline Sarcomatoid carcinoma & $\begin{array}{l}\text { Grade } 5 \text { (glands graded } \\
\text { separately) }\end{array}$ \\
\hline Lymphoepithelioma-like carcinoma & Not graded \\
\hline Small-cell carcinor & Not graded \\
\hline $\begin{array}{l}\text { Urothelial (transitional cell) } \\
\text { carcinoma }\end{array}$ & Not graded \\
\hline $\begin{array}{l}\text { Undifferentiated carcinoma, not } \\
\text { otherwise specified }\end{array}$ & Not graded \\
\hline Pseudohyperplastic & Grade 2 or 3 , very rarely \\
\hline Xanthomatous (foamy gland) & Most grade 3 or 4 \\
\hline Atrophic & Grade 3, occasionally 2 \\
\hline
\end{tabular}

${ }^{\mathrm{a}}$ From: Amin MB, Grignon DJ. Humphrey PA, Srigley JR. Gleason Grading of Prostate Cancer: A Contemporary Approach. Lippincott, Williams \& Wilkins: Philadelphia, PA, 2004.

prognosis than usual acinar adenocarcinoma. ${ }^{15}$ In a recent report, Brinker et $a{ }^{16}{ }^{16}$ reported that the presence of ductal adenocarcinoma in needle biopsy specimens was associated with a higher frequency of advanced pathologic stage and a shorter time to progression.

Although these tumors are classically described as being centrally located, it is not uncommon to see identical patterns in the periphery of the gland only. There are no specific gross characteristics. Histologically, the tumor grows in a mixture of papillary, cribriform and solid patterns, with and without central (comedo) necrosis. Some authors have subdivided these into two types based on predominant involvement of primary (large) or secondary (small) ducts. ${ }^{9}$ The papillae are often complex and branching and can be fused (Figure 1). The papillary fronds are covered by a pseudostratified epithelium that may closely resemble endometrial carcinoma (Figure 2) or the cells may have cleared cytoplasm. The cells are often columnar and nuclei are large, oval to round and typically contain a single macronucleus (Figure 3). Mitoses are frequently

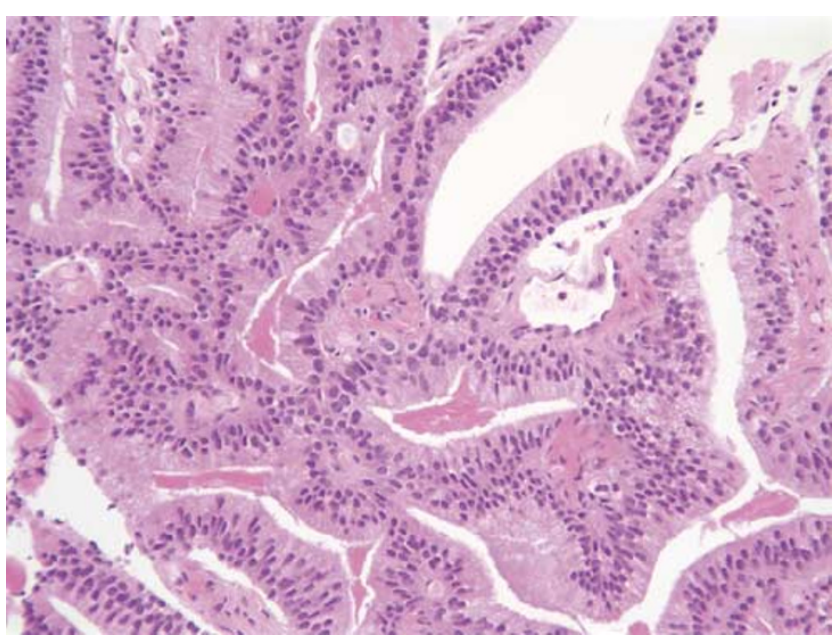

Figure 1 Ductal adenocarcinoma. Complex, branching architecture typical of prostatic ductal adenocarcinoma. Papillae are covered by a pseudostratified columnar epithelium.

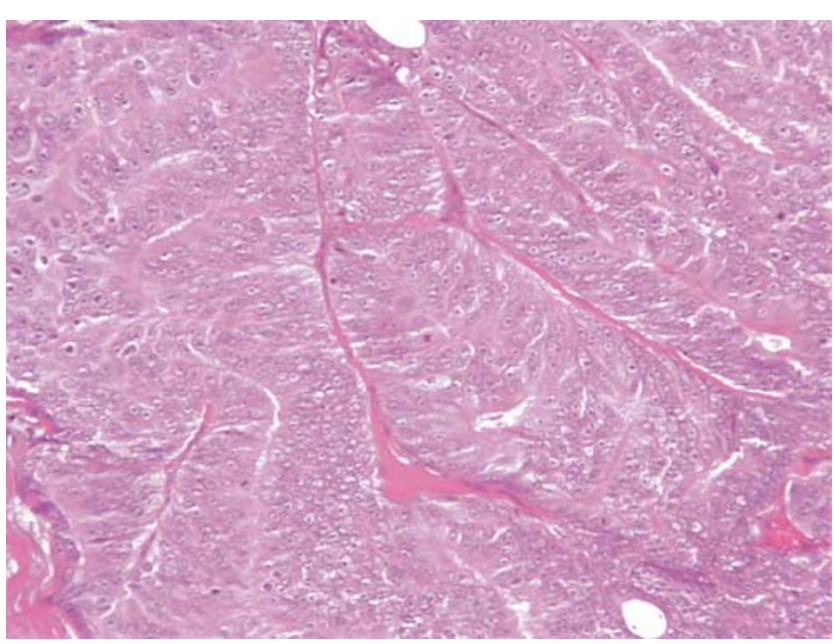

Figure 2 Ductal adenocarcinoma. In type 2 tumors, there is more pronounced stratification resulting in an appearance reminiscent of endometrial adenocarcinoma.

present. In some cases, the morphology closely mimics urothelial (transitional cell) carcinoma. In practically all cases, the cells are at least focally PSA- and PAP-positive.

The Gleason grade assigned depends on the architecture and ranges from grade 3 (well-circumscribed cribriform nests) to grade 4 (more irregular papillary cribriform masses) to grade 5 (when comedonecrosis is present; Figure 4). Gleason considered most of these to fit in the grade 3 group $^{17}$ and this approach has been followed by some authorities, ${ }^{18}$ while others have not graded these tumors. ${ }^{19}$ Based on available outcome data, it is clear that these behave much more like grade 4 than grade 3 carcinomas. ${ }^{15,16}$ The majority of cases with a predominantly ductal pattern are assigned Gleason scores of 8 or $9 . .^{3}$ In most cases $(>80 \%)$, there is a typical small acinar component present. 


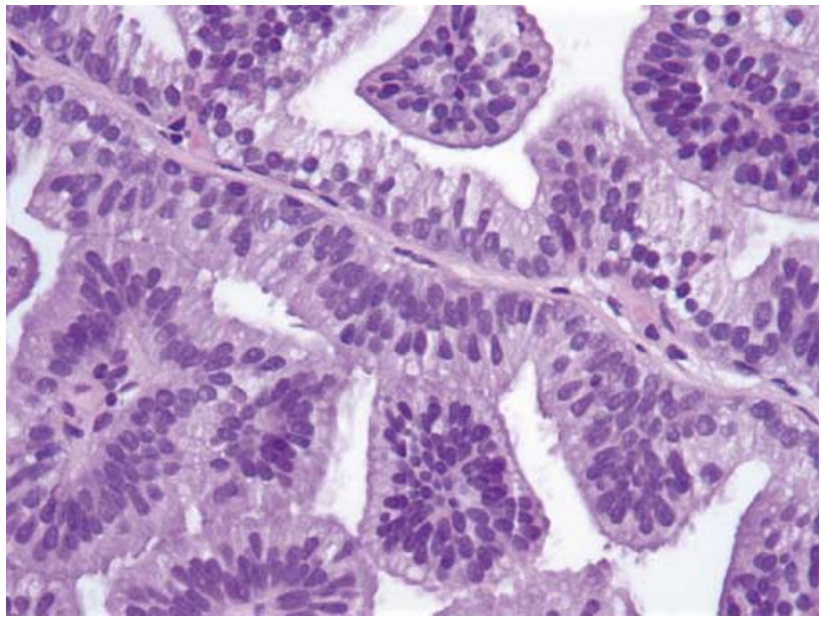

Figure 3 Ductal adenocarcinoma. High-power photomicrograph illustrating tall columnar cells with pale to clear cytoplasm and large ovoid nuclei.

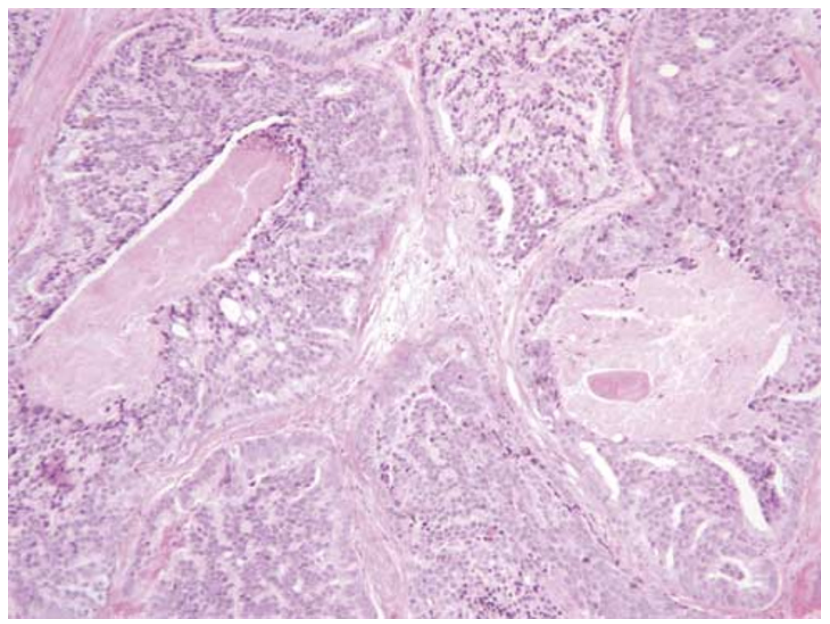

Figure 4 Ductal adenocarcinoma. Complex papillary cribriform architecture with central comedonecrosis.

The differential diagnosis includes three major considerations. The papillary architecture can suggest urothelial carcinoma in TUR material from the urethra and in biopsies taken from the bladder trigone. Nuclear features are very helpful in this differential; in urothelial carcinoma the nuclei are pleomorphic with angulated nuclear outlines and variable numbers and sizes of nucleoli. In ductal adenocarcinoma, the nuclei are more uniform, virtually all being large, round to oval and containing a single macronucleus. Urothelial carcinoma frequently spreads into ducts in a pagetoid manner, a pattern rare in ductal carcinoma. The possibility of a rectal adenocarcinoma invading the prostate also needs to be considered and if there is a significant difficulty PSA and PAP immunostaining is usually diagnostic. Finally, the problem of where the morphologic spectrum of HGPIN ends and ductal adenocarcinoma begins can be problematic. Obvious cases of ductal adenocarcinoma can have residual basal cells and so high molecular weight cytokeratin may not be of value. ${ }^{20}$ Generally, if the ductal structures are confluent or back-to-back, and are expanded, I will make a diagnosis of cancer even in needle biopsy specimens.

\section{Mucinous (colloid) carcinoma}

Pure mucinous carcinomas of the prostate are exceedingly rare and so most authors have used this designation only if more than $25 \%$ of the tumor volume consists of extravasated mucin. ${ }^{1,21-23}$ Using these criteria, these tumors have an incidence of approximately $0.2 \% .{ }^{21-23}$ There are no clinical features to distinguish mucinous carcinoma from usual acinar adenocarcinoma. These tumors cause elevated PSA, metastasize in the usual manner and respond to hormonal therapy. ${ }^{21-25}$ This variant is considered to be associated with a worse prognosis than usual acinar adenocarcinoma. In a literature review of 60 mucinous carcinomas, Saito and Iwaki $^{26}$ found the 3 - and 5 -year survivals to be 50 and $25 \%$, respectively.

Grossly, the tumors may have a mucoid or gelatinous cut surface. Histologically, pools of extravasated mucin are present in the stroma with suspended nests, cords or groups of carcinoma cells forming acini (Figure 5). Single cells, including signet ring forms may be found. Cytoplasmic mucin is usually not demonstrable. The presence of luminal mucin is seen in up to one-third of prostatic adenocarcinomas including both acinar and cribriform types and is not sufficient to apply this term. ${ }^{27}$ In the histochemical study of Saez et $a{ }^{28}$ the mucins in mucinous carcinoma were much more frequently $O$-acetylated than the luminal mucin in Gleason pattern 3 acinar carcinoma suggesting a fundamental difference between these patterns. Neuroendocrine and Paneth-like cells can be present. ${ }^{29}$ Collagenous micronodules are often present (Figure 6). Mucinous carcinoma is considered to be a Gleason grade 4 pattern.

The major differential diagnosis is with secondary prostatic involvement by a mucinous adenocarcinoma arising elsewhere (usually rectum or bladder). The presence of associated typical acinar prostatic adenocarcinoma, and the cytologic features of the tumor cells, make this distinction straightforward in most instances. If necessary, PSA and PAP immunostaining will resolve the question. In patients treated with hormone ablation, acellular pools of mucin can be left behind mimicking mucinous carcinoma. ${ }^{30}$

\section{Signet ring cell carcinoma}

Pure signet ring cell carcinoma of the prostate gland is vanishingly rare. ${ }^{15}$ Most often signet ring cells are seen as a minority population in high grade (often grade 5) adenocarcinomas. Designation as a signet 


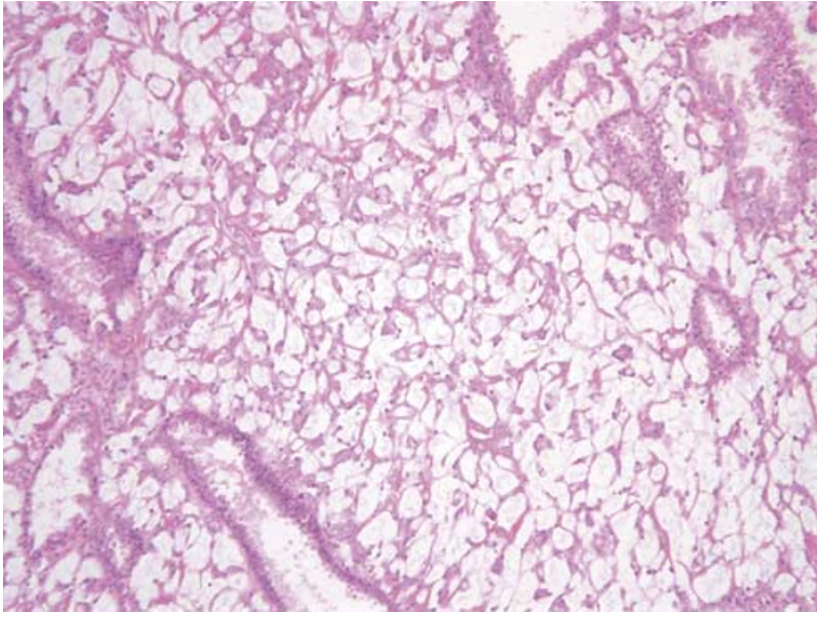

Figure 5 Mucinous carcinoma. Radical prostatectomy specimen with extensive extravasated mucin containing suspended tumor cells. Note the residual non-neoplastic glands in the background.

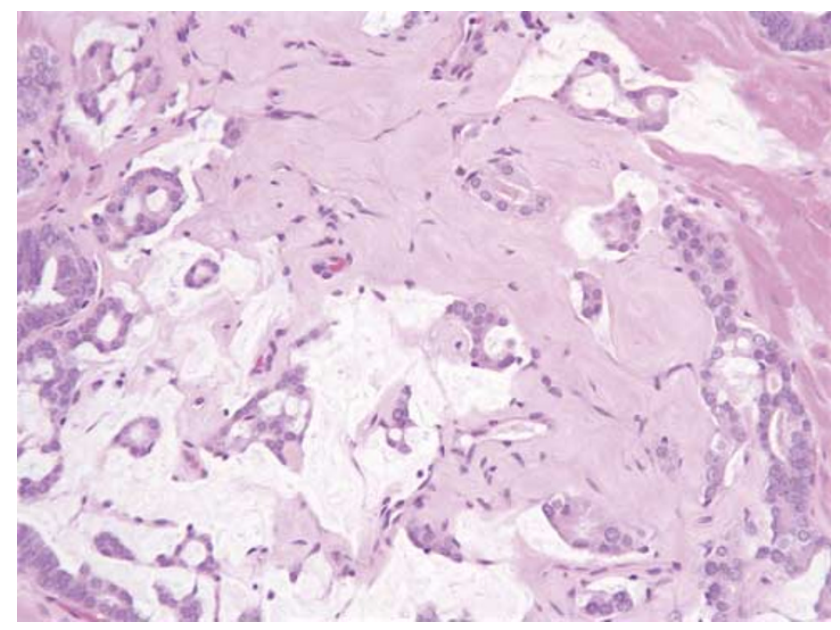

Figure 6 Mucinous carcinoma. Extravasated mucin with suspended malignant glands and extensive collagenous micronodule formation.

ring cell carcinoma is restricted to those cases where the signet ring cells make up over $25 \%$ of the tumor volume, although a wide range of definitions have been applied. ${ }^{31-38}$

Clinically, these tumors are typically of advanced stage at the time of diagnosis. ${ }^{15,26,36}$ Serum PSA is usually significantly elevated. ${ }^{37}$ There are no other specific features associated with these tumors. In a review of 17 cases from the literature, Saito and Iwaki ${ }^{26}$ found a 3 -year survival of only $27 \%$.

There are no specific gross features for signet ring cell carcinoma. Typically, the signet ring cells represent a minority population in an otherwise typical though high-grade carcinoma. The cells may be arranged in sheets, small clusters or as single cells (Figure 7). The cells are characterized by a clear cytoplasmic vacuole displacing the nucleus to one side. In most cases, the vacuole represents intracytoplasmic lumen formation and the cells are mucin

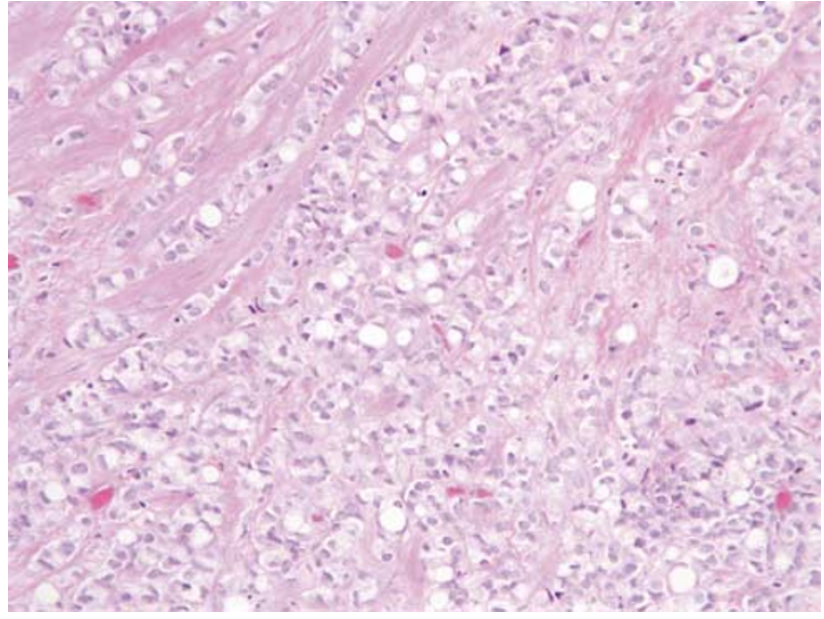

Figure 7 Signet ring cell carcinoma. Tumor cells diffusely infiltrating the prostate stroma. Many cells have prominent cytoplasmic vacuoles displacing the nuclei and forming signet ring cells.

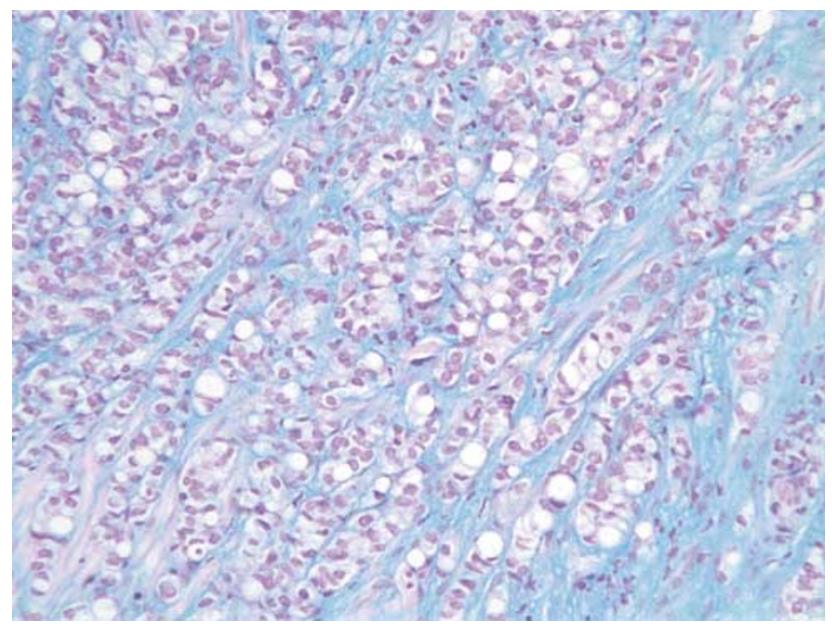

Figure 8 Signet ring cell carcinoma. Alcian blue stain on same case as Figure 7 showing the absence of mucin in the signet ring cells.

negative ${ }^{32,26}$ (Figure 8). A minority of cells may be mucin-positive, but generally with weak staining. ${ }^{34}$ The tumor cells are PSA- and PAP-positive. Signet ring cell areas are considered grade 5 . Signet ring cells can be present in well-formed or fused glands of grades 3 and 4; in this situation, their presence should not influence the grade assignment. ${ }^{3}$

The major differential diagnosis is with secondary signet ring cell carcinoma. In rare pure cases, mucin, PSA and PAP stains will sort out the differential. ${ }^{37}$ It is also important to remember that both lymphocytes and benign stromal cells in the prostate can have a signet ring cell-like change. ${ }^{39,40}$ In challenging cases, negative staining for cytokeratin, PSA and PAP combined with positive reactivity for lymphoid or mesenchymal markers can resolve the case. 


\section{Adenosquamous and squamous cell carcinoma}

Primary squamous cell carcinoma of the prostate is exceedingly rare. ${ }^{41-47}$ It has been reported in the setting of Schistosomiasis infection. ${ }^{48}$ Suggested criteria for a diagnosis of squamous cell carcinoma of the prostate include (i) the presence of unequivocal features of malignancy, (ii) the presence of definitive squamous differentiation, (iii) lack of a conventional carcinoma component, (iv) no prior treatment with radiation or hormones and (v) no squamous cell carcinoma elsewhere.

In general, these tumors present similarly to usual prostatic carcinoma. In pure tumors, PSA and PAP are usually not elevated. In most cases, the tumor is locally advanced and bone metastases can be osteolytic rather than osteoblastic. There is insufficient experience with these tumors to make any specific comments regarding prognosis and treatment responsiveness, although mean survival in reported cases of squamous and adenosquamous carcinomas has only been six months. ${ }^{15}$

There are no typical gross features. Histologically, these are squamous carcinomas and can show variable differentiation. These are not graded using the Gleason system, as they are not adenocarcinomas. Adenosquamous carcinoma refers to those cases with a mixture of glandular and squamous differentiation (Figure 9).$^{4-52}$ This is also a rare neoplasm and in my experience is most often seen in association with hormonal therapy. It has been recommended that these tumors also not be Gleason graded. ${ }^{3}$ Cases have been described in the absence of hormonal therapy. In these cases, the glandular element is clearly of prostatic origin and stains positively for PSA and PAP. The squamous component shows variable reactivity for these markers, but has been negative in my experience.

The major differential diagnosis is with urothelial carcinoma that can show squamous differentiation.

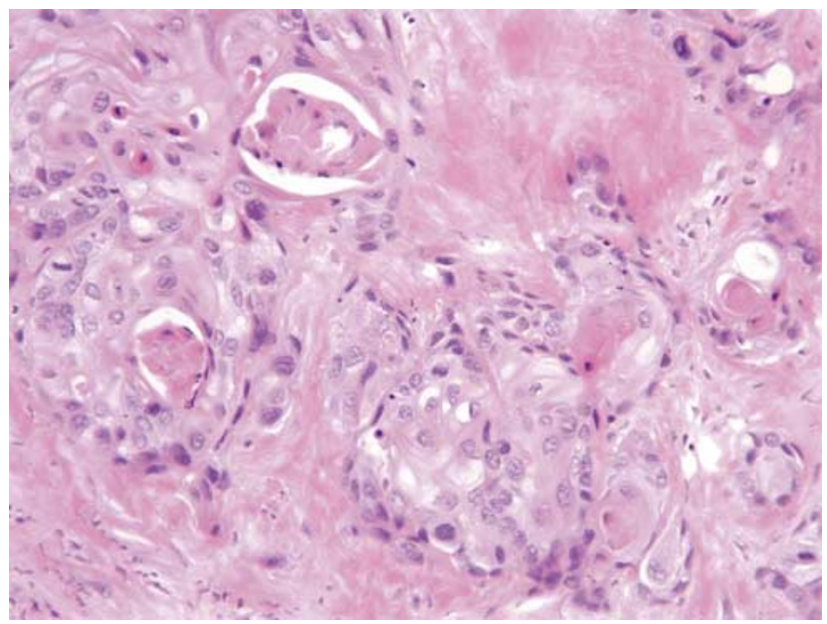

Figure 9 Adenosquamous carcinoma. Poorly differentiated adenocarcinoma with squamous differentiation in a patient that had been treated with diethylstilbestrol.
Outside of the setting of known prostatic adenocarcinoma being treated with hormones, the presence of squamous differentiation in a high-grade carcinoma should always suggest this possibility. Furthermore, urothelial carcinoma and prostatic adenocarcinoma often coexist and so identification of an acinar component does not necessarily exclude this possibility. Clinical correlation should be sought in this situation. The differential diagnosis also includes squamous metaplasia, a change most often associated with hormonal therapy or prostatic infarction. In the latter, reactive atypia can be pronounced.

\section{Basaloid and adenoid cystic carcinoma}

Basal cell lesions in the prostate gland span a wide range from obviously benign basal cell hyperplasia through varying ranges of atypia to lesions that have been described under the terms basal cell carcinoma and adenoid cystic carcinoma. ${ }^{53-63}$ This remains an area of considerable uncertainty without welldefined criteria for predicting the behavior of these lesions. ${ }^{64}$ Most experts do acknowledge the presence of a malignant end to the spectrum. ${ }^{1,15,19,64}$ Clinically, these occur over a wide age range with no specific characteristics; PSA has been reported to be elevated in some cases. ${ }^{61}$ Given the limited clinical outcome data available, it has been suggested that these be 'viewed as a neoplasm of low malignant potential'. ${ }^{15}$

Criteria for the diagnosis of malignancy in basal cell lesions remain unclear. Features suggested to indicate malignant potential include an invasive growth pattern including extensive infiltration between benign prostatic glandular elements, perineural invasion and extraprostatic extension; the presence of necrosis; and the presence of metastases. ${ }^{64}$ Yang et al. ${ }^{60}$ found high expression of bcl-2 and Ki-67 to distinguish basaloid carcinoma from basal cell hyperplasia (usual and atypical). In adenoid cystic carcinoma, the cells are arranged in irregular nests with a cribriform architecture reminiscent of adenoid cystic carcinoma elsewhere. Ultrastructural studies have demonstrated basal lamina production and glandular lumen formation. ${ }^{56}$ In the basaloid pattern, the nests range from rounded to large and irregular (Figures 10 and 11). The two often coexist. Individual cells have large pleomorphic nuclei and scant cytoplasm. The nuclei are often angulated with tapered ends and the cells fusiform or spindled. In the invasive tumors, there is usually a prominent stromal response that often has a myxoid nature. Given the unique nature of these lesions and the limited clinical outcome data available, Gleason grading of these tumors is not recommended. ${ }^{3}$

Immunohistochemical staining is variable with most cases showing at least focal positivity for high molecular weight cytokeratin. Similarly focal 


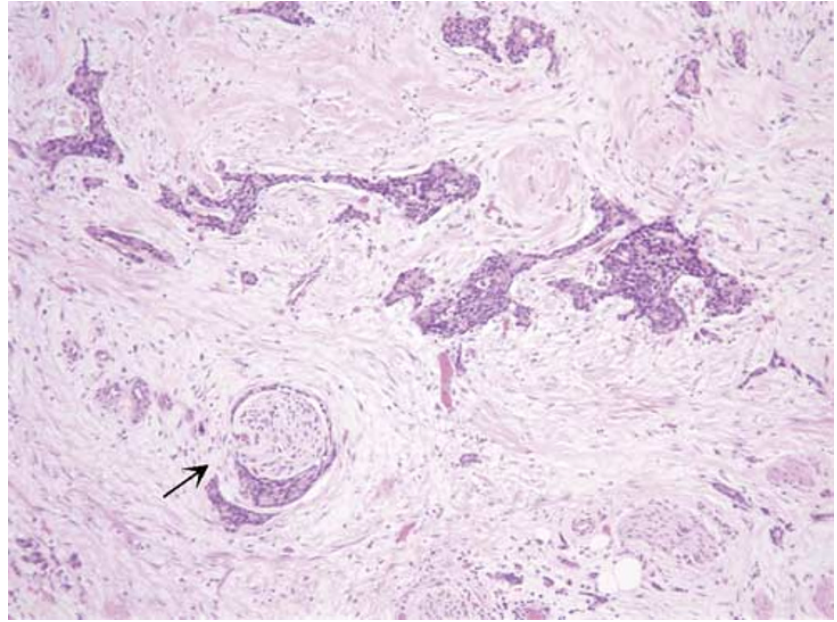

Figure 10 Basaloid carcinoma. Poorly differentiated tumor with cells having scant to moderate cytoplasm and eosinophilic material within the nests. Note also the prominent perineural invasion (arrow) and stromal desmoplasia.

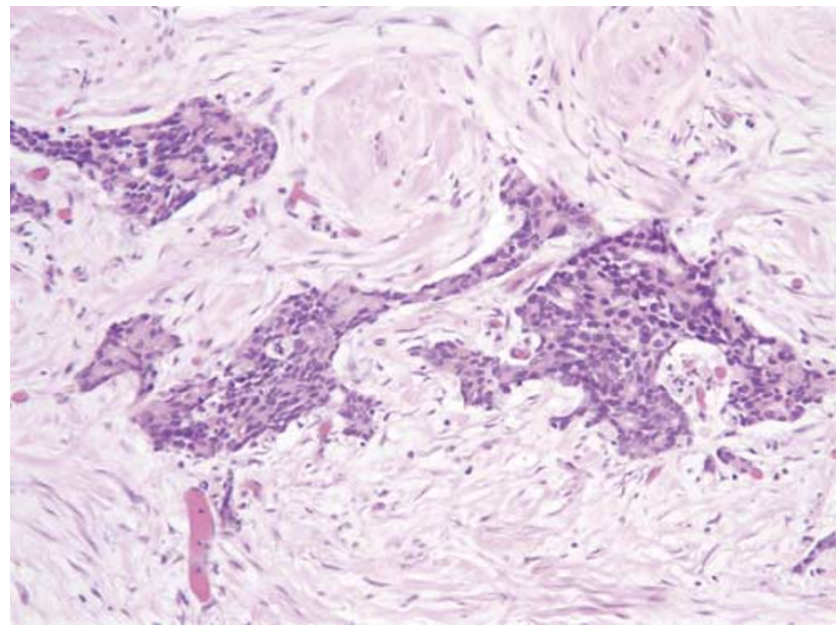

Figure 11 Basaloid carcinoma. Higher power photomicrograph of same case as Figure 10 highlighting the cytologic details of the tumor cells.

positivity for PSA and PAP may be present but is inconsistent. Scattered chromogranin-positive cells have been reported. ${ }^{55,56,58,62}$ In cases studied, S100 protein and muscle-specific actin stains have been negative. ${ }^{55,56}$

\section{Sarcomatoid carcinoma}

Sarcomatoid carcinoma or carcinosarcoma refers to a tumor with mixed epithelial and mesenchymal differentiation. Some authors use the term carcinosarcoma if there are heterologous elements and sarcomatoid carcinoma if there are not; however, there is no clinical or biologic data to support this distinction. ${ }^{15}$ These tumors are rare, but do occur in the prostate gland..$^{65-72}$

Clinically, these patients tend to be older and in roughly half of cases have a history of prostatic

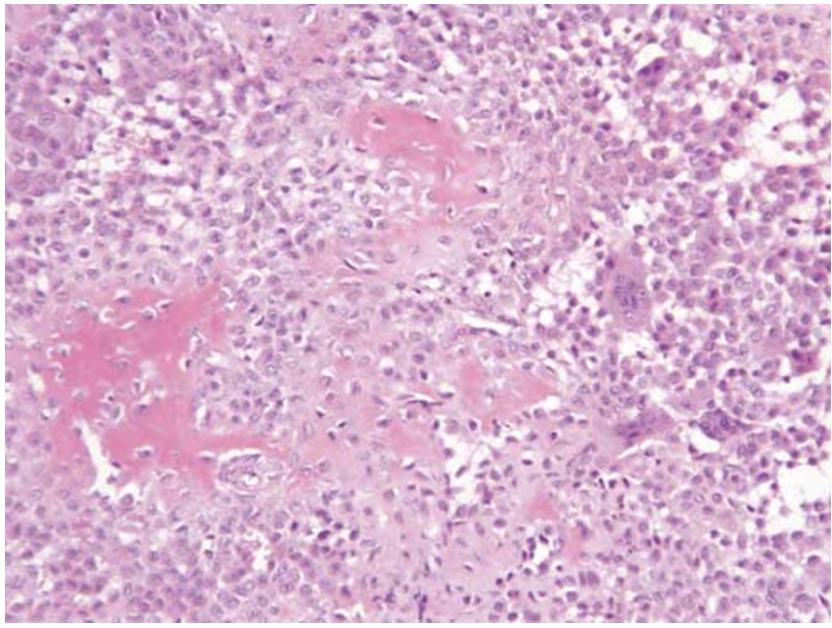

Figure 12 Sarcomatoid carcinoma. Poorly differentiated carcinoma with areas of osteoid formation.

adenocarcinoma treated by radiation. ${ }^{66,68}$ The tumors produce bladder outlet obstruction and often require repeated TURs to control local symptoms. Serum PSA levels are usually lower than expected for the tumor volume. These are associated with a very poor prognosis with local recurrence and uncontrollable disease in the pelvis. In the largest published series, 5- and 7-year survivals were 41 and $14 \%$, respectively. ${ }^{68}$

Pathologically, there is a mixture of epithelial and mesenchymal elements. The epithelial component is usually of high grade and the acinar type. The mesenchymal component is often a high-grade spindle cell tumor without specific differentiation. Heterologous elements can be present with ostosarcoma and chondrosarcoma being most common (Figures 12 and 13). The sarcomatoid component is considered to be Gleason grade 5 , with the glandular element, if present, assigned a grade according to the usual rules. ${ }^{3}$ Given the distinctive clinical behavior of these tumors, it is recommended that the presence of sarcomatoid histology be included in the diagnosis. ${ }^{3}$ The epithelial component is cytokeratin, PSA- and PAP-positive. In a minority of cases, the spindle cell element expresses cytokeratin, but PSA and PAP are rarely positive.

The major differential diagnosis is primary prostatic sarcoma. ${ }^{66,68,73}$ In adults, these are almost always leiomyosarcoma and will stain appropriately. In recurrent tumors, the mesenchymal component usually overgrows the epithelial and so a pure sarcomatous pattern in the setting of pretreated adenocarcinoma should be assumed to represent sarcomatoid carcinoma. Benign spindle cell proliferations such as inflammatory myofibroblastic tumor (pseudosarcomatous fibromyxoid tumor) and postoperative spindle cell nodule can be confused with the mesenchymal component of sarcomatoid carcinoma. Significant cytologic atypia, abnormal mitotic figures and necrosis would favor a malignant diagnosis. 


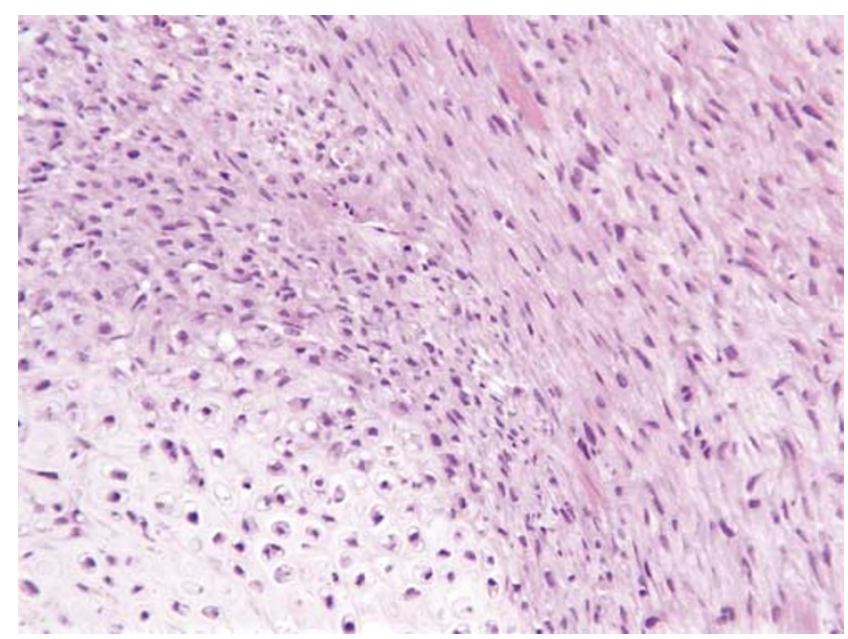

Figure 13 Sarcomatoid carcinoma. In this case, there is a spindle cell component and chondroid formation.

\section{Lymphoepithelioma-like carcinoma}

Tumors that morphologically resemble lymphoepithelioma of the nasopharynx have been reported in numerous body sites including the prostate gland. These are extremely rare with only a single case described. ${ }^{74}$ In that case, the lymphoepitheliomalike carcinoma was admixed with a typical small acinar adenocarcinoma. The clinical significance of this morphology in the prostate is unknown and so assignment of a Gleason grade is not recommended. ${ }^{3}$

\section{Small-cell (neuroendocrine) carcinoma}

Neuroendocrine cells are frequently identifiable in usual acinar type adenocarcinoma of the prostate. ${ }^{75}$ In some immunohistochemical studies, up to $100 \%$ of prostate adenocarcinomas contain chromograninpositive cells. ${ }^{75}$ In a minority of cases, these cells are identifiable on hematoxylin-and-eosin-stained sections by the presence of coarse eosinophilic cytoplasmic granules. ${ }^{76}$ In most cases, however, they are not identifiable without immunohistochemical techniques. Cases with these features are not included in the small-cell carcinoma category.

The term small-cell carcinoma is restricted to those cases, either pure or mixed with an adenocarcinoma component, where the cells fulfill the light microscopic criteria for small-cell carcinoma of the lung (and elsewhere). Defined in this way, smallcell carcinoma is an uncommon prostatic tumor, but with important and distinctive clinicopathologic characteristics. ${ }^{77-87}$

Clinically, small-cell carcinoma may arise de novo and be identified at the time of initial diagnosis. More often, however, the small-cell component manifests itself late in the course of a patient with documented metastatic prostate cancer. In my experience, the most common clinical scenario is a patient with bone metastases on hormonal therapy who suddenly develops widespread metastases in unusual locations (eg liver), without an accompanying rise in the serum PSA. Soft-tissue metastases are characteristic and bone metastases are osteolytic. Papandreou et al. ${ }^{87}$ highlighted this scenario as an indication to biopsy the metastatic site to look for a small-cell element. Prognosis in this situation is very poor. In the de novo situation, the prognosis is also poor and usually the patient will be offered cisplatin-based chemotherapy as part of the treatment plan; these tumors are nonresponsive to androgen ablation. ${ }^{77,81,86,87}$ Median survival is less than 12 months following identification of smallcell carcinoma with pure tumors doing slightly worse than mixed tumors. A variety of paraneoplastic syndromes have been reported in association with small-cell carcinoma. ${ }^{15}$

Pathologically, the small-cell component is identical to similar tumors in the lung. Oat cell and intermediate cell patterns can be seen. The tumor grows in sheets or nests with geographic areas of necrosis (Figure 14). Other typical features of smallcell carcinoma, including high mitotic rate, frequent apoptotic bodies, crush artifact and DNA encrustation of blood vessel walls (Azzopardi phenomenon) are present (Figure 15). Although some authors assign this a Gleason grade of 5, others including myself consider small-cell carcinoma to be a distinct tumor type, with specific therapeutic implications, and do not Gleason grade these tumors. ${ }^{3,19}$ It is important to remember that the diagnosis does not require proof of neuroendocrine differentiation by immunohistochemistry or electron microscopy, although the small-cell component often shows the characteristic dot-like cytokeratin immunopositivity and positivity for one or more neuroendocrine markers (chromogranin, synaptophysin, etc) ${ }^{80,84,88}$ In over one-half of cases, a typical acinar component is present and in some instances apparent merging of one pattern with the other is seen (Figure 16). The acinar component is PSA- and PAP-positive, while the small-cell component is generally negative with these markers.

The major differential diagnosis is with secondary small-cell carcinoma (particularly of bladder origin) and malignant lymphoma. Clinical correlation is necessary to exclude the former; immunohistochemistry readily resolves the latter. Carcinoid tumors can also arise in the prostate and should be distinguished from small-cell carcinoma.

\section{Urothelial (transitional cell) carcinoma}

Urothelial carcinoma may be primary in the prostate gland or represent secondary spread from the urinary bladder. The frequency of primary urothelial carcinoma ranges from 0.7 to $2.8 \%$ of prostatic tumors in adults. ${ }^{89,90}$ Most patients are older with a similar age distribution to urothelial carcinoma of the bladder (range $45-90$ years). ${ }^{89,91}$ In patients with 


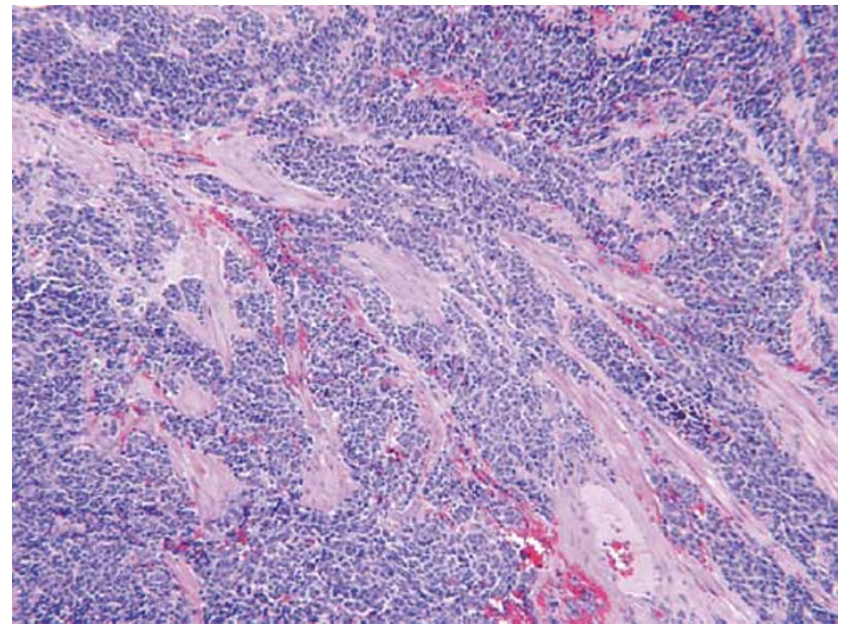

Figure 14 Small-cell carcinoma. Low-power photomicrograph of a case with both small-cell and adenocarcinoma components.

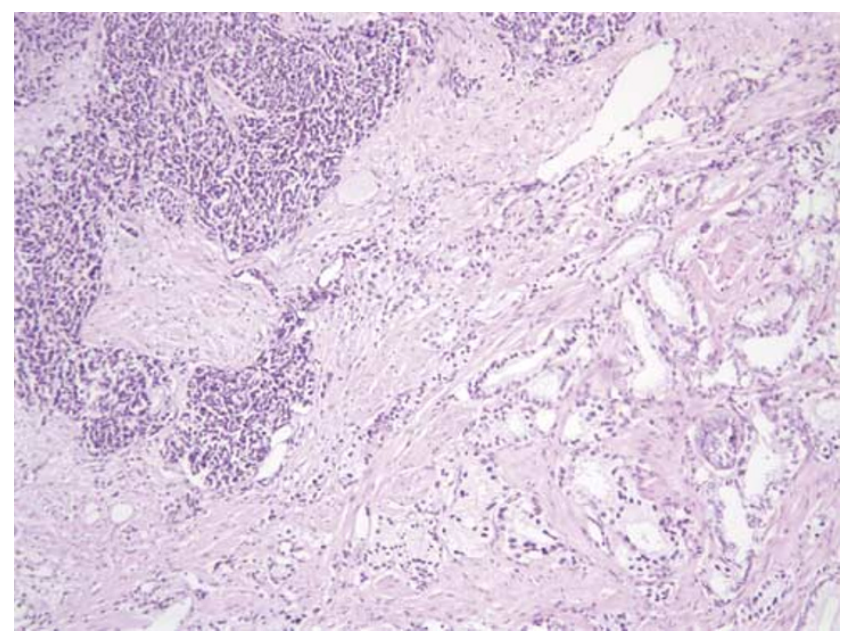

Figure 15 Small-cell carcinoma. Small-cell component of same case as Figure 14 illustrating typical morphologic features of small-cell carcinoma.

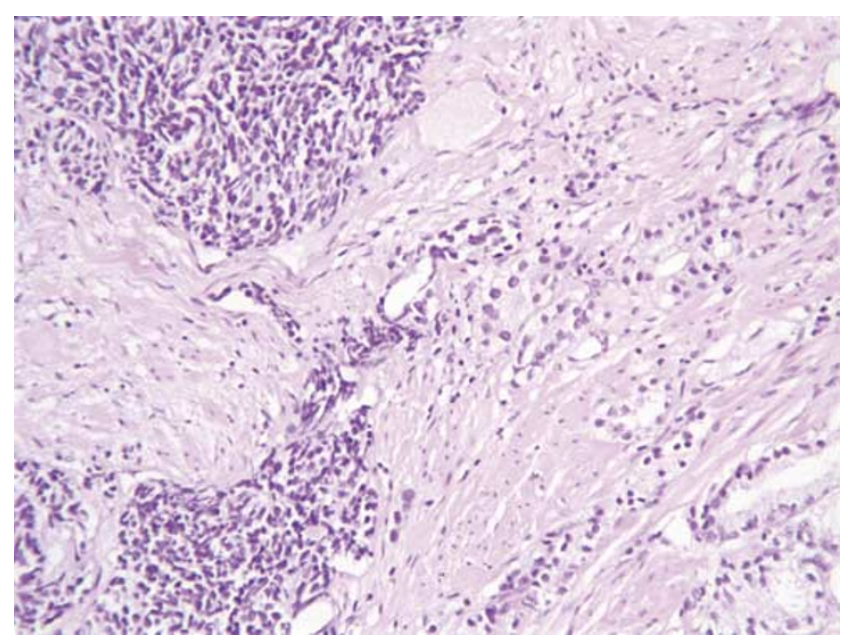

Figure 16 Small-cell carcinoma. High-power photomicrograph illustrating both the small-cell and adenocarcinoma components in this case with mixed differentiation. invasive bladder carcinoma, there is involvement of the prostate gland in up to $45 \%$ of cases. ${ }^{92-94}$ This is highest when there is multifocality or carcinoma in situ associated with the invasive carcinoma. ${ }^{93}$

Primary urothelial carcinomas presumably arise from the urothelium lining the prostatic urethra and the proximal portions of prostatic ducts. It has been postulated that these may develop through a hyperplasia to dysplasia sequence, possibly from reserve cells within the urothelium. ${ }^{95-97}$

Primary urothelial carcinoma presents in a manner similar to other prostatic masses including urinary obstruction and hematuria. ${ }^{90,98}$ Digital rectal examination is abnormal in the majority, but is infrequently the presenting sign. ${ }^{99}$ There are limited data on PSA levels in patients with urothelial carcinoma of the prostate. In one series, four of six patients had elevated serum PSA ( $>4 \mathrm{ng} / \mathrm{ml})$ in the absence of prostatic adenocarcinoma. ${ }^{99}$ In some cases, patients present with signs and symptoms related to metastases. ${ }^{98}$ Most cases are diagnosed by TUR or less often needle biopsy. ${ }^{99}$ In all suspected cases, the possibility of secondary involvement from a bladder primary must be excluded; the bladder tumor can be occult and random biopsies of urinary bladder mucosa may be necessary to exclude this possibility. ${ }^{64,100}$

Primary urothelial carcinoma arising in the prostatic urethra or prostatic ducts can spread along ducts and involve acini or similar to bladder carcinoma in situ, tumor can spread along ejaculatory ducts and into seminal vesicles. Initial spread is by invasion of prostatic stroma. Local spread beyond the confines of the prostate gland may occur. Metastases are to regional lymph nodes and bone. ${ }^{101}$ Bone metastases are osteolytic. These tumors are staged in the AJCC system under tumors of the urethra (see Table 3). ${ }^{102}$ For tumors involving the prostatic ducts, there is a T1 category for invasion of subepithelial connective tissue distinct from invasion of prostatic stroma (T2). The prognostic importance of these categories has been confirmed in clinical studies. ${ }^{103}$

The full range of histologic types and grades of urothelial neoplasia can be seen in primary urothelial neoplasms of the prostate. ${ }^{103} \mathrm{~A}$ few examples of papillary urothelial neoplasms arising within prostatic ducts are described. ${ }^{96}$ The vast majority, however, are of high grade and are associated with an in situ component. ${ }^{99,98,103-107}$ The in situ component has the characteristic histologic features of urothelial carcinoma in situ elsewhere with marked nuclear pleomorphism, frequent mitoses and apoptotic bodies (Figure 17). A single cell pattern of pagetoid spread or burrowing of tumor cells between the basal cell and secretory cell layers of the prostate is characteristic (Figure 18). Central comedonecrosis is frequent (Figure 19). Stromal invasion is associated with a prominent desmoplastic stromal response with tumor cells arranged in small irregular nests, cords and single cells. Inflammation in the 
Table 3 Urothelial carcinoma of prostate-T categories (2002)

\begin{tabular}{ll}
\hline Category & Description \\
\hline Tis pu & Carcinoma in situ, involvement of prostatic urethra \\
Tis pd & Carcinoma in situ, involvement of the prostatic ducts \\
T1 & Tumor invades subepithelial connective tissue \\
T2 & Tumor invades any of the following: prostatic stroma, corpus spongiosum, periurethral muscle \\
T3 & Tumor invades any of the following: corpus cavernosum, beyond prostatic capsule, bladder neck (extraprostatic extension) \\
T4 & Tumor invades other adjacent organs (invasion of the bladder)
\end{tabular}

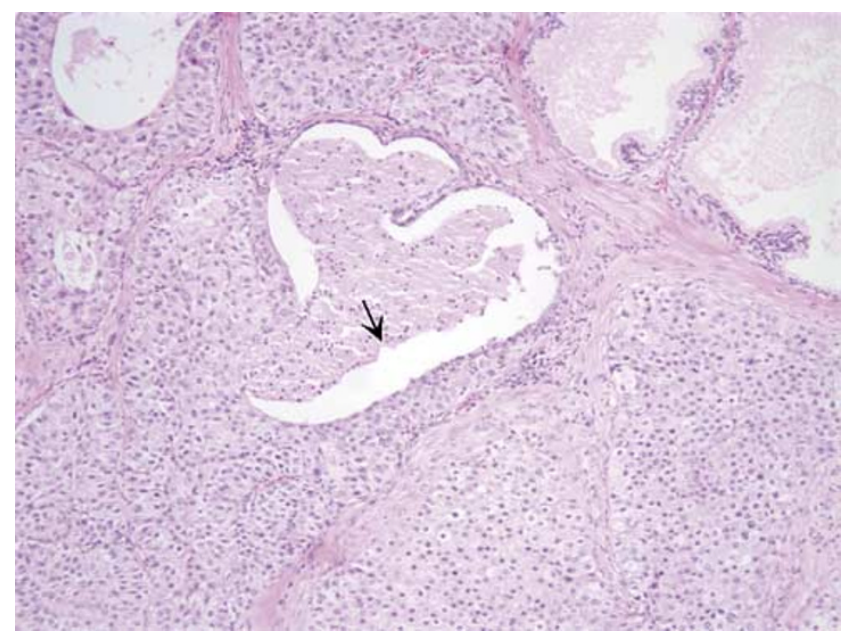

Figure 17 Urothelial carcinoma. Urothelial carcinoma in situ filling and expanding normal ductal and glandular structures. Note the undermining of residual prostatic secretory cells in the large duct in the center (arrow).

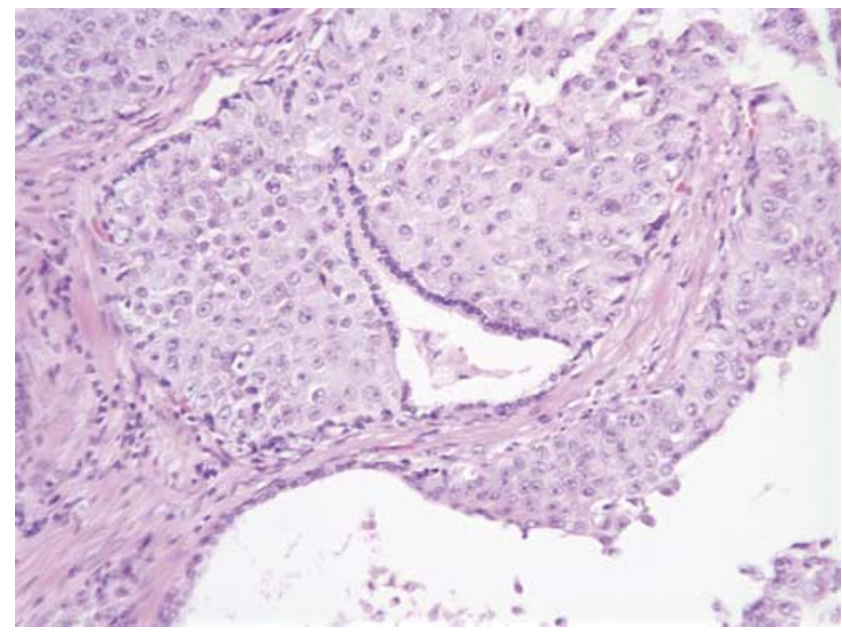

Figure 18 Urothelial carcinoma. High-power photomicrograph illustrating pagetoid spread of the tumor undermining residual secretory cells.

adjacent stroma frequently accompanies in situ disease, but without desmoplasia (Figure 20). Squamous or glandular differentiation can be seen. Angiolymphatic invasion is often identified. Incidental adenocarcinoma of the prostate is found in

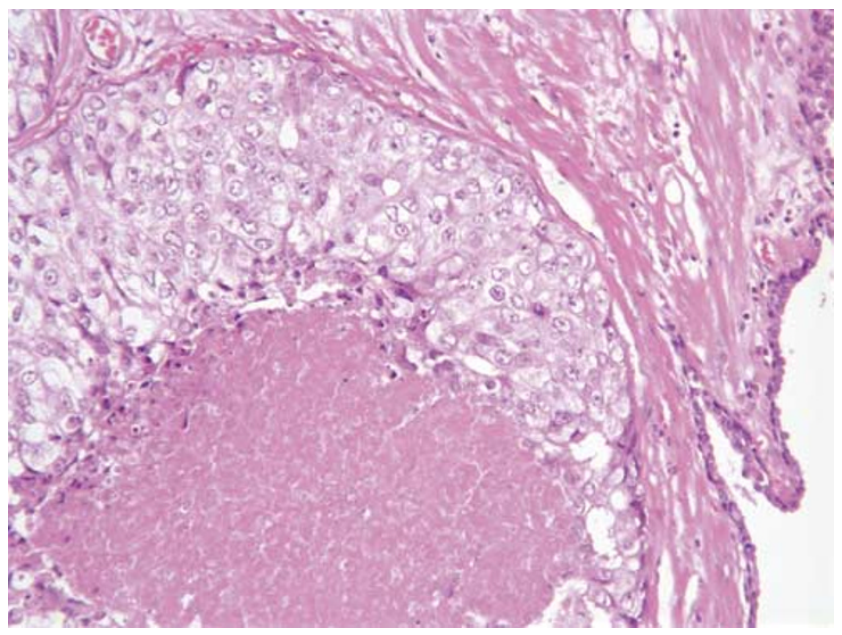

Figure 19 Urothelial carcinoma. Urothelial carcinoma in situ in a prostatic duct with prominent comedonecrosis. Note the degree of nuclear pleomorphism in the tumor cells.

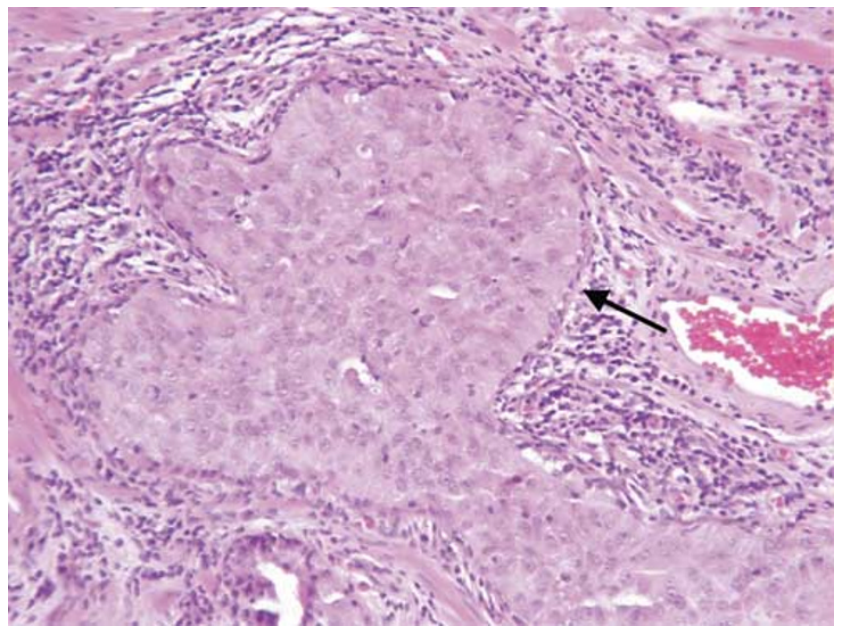

Figure 20 Urothelial carcinoma. Urothelial carcinoma in situ in a prostatic duct with residual basal cells visible (arrow). Chronic inflammation present in the adjacent stroma does not necessarily indicate the presence of stromal invasion.

up to $40 \%$ of cystoprostatectomy specimens removed for urothelial carcinoma of the bladder and can accompany primary urothelial carcinoma. ${ }^{94}$

The tumor cells are negative for PSA and PAP. ${ }^{99,108}$ Secretions in the ductal lumens can react positively 
resulting in faint staining of tumor cells at the luminal surface, a finding that should not be misinterpreted as positive staining. Tumor cells express CK7 and CK20 in the majority of cases and high molecular weight cytokeratin in under 50\%. ${ }^{108}$ Residual basal cells are frequent in the in situ areas. ${ }^{99}$

For patients with urothelial carcinoma of the prostate, the single most important prognostic parameter is the presence or absence of prostatic stromal invasion. In one series, the survival was $100 \%$ for patients with noninvasive disease treated by radical cystoprostatectomy. ${ }^{103}$ With stromal invasion or extension beyond the confines of the prostate prognosis is poor. ${ }^{90,103,109,110}$ In a Mayo Clinic series, the overall survival was $45 \%$ at 5 years in 19 patients with stromal invasion. ${ }^{103}$ In 10 cases of primary urothelial carcinoma, reported by Goebbels et $a{ }^{107}$ the mean survival was 28.8 months (range 1-93 months).

\section{References}

1 Randolph TL, Amin MB, Ro JY, et al. Histologic variants of adenocarcinoma and other carcinomas of the prostate: pathologic criteria and clinical significance. Mod Pathol 1997;10:612-629.

2 Gleason DF. Classification of prostatic carcinoma. Cancer Chemother Rep 1966;50:125-128.

3 Amin MB, Grignon DJ, Humphrey PA, et al. Gleason Grading of Prostate Cancer: A Contemporary Approach. Lippincott, Williams \& Wilkins: Philadelphia, PA, 2004.

4 Melicow MM, Pachter MR. Endometrial carcinoma of the prostatic utricle (uterus masculinus). Cancer 1976;20:1715-1721.

5 Melicow MM, Tannenbaum M. Endometrial carcinoma of uterus masculinus (prostatic utricle): report of 6 cases. J Urol 1971;106:892-902.

6 Zaloudek C, Williams JW, Kempson RL. 'Endometrial' adenocarcinoma of the prostate: a distinctive tumor of probable prostatic ductal origin. Cancer 1976;37: 2255-2262.

7 Bostwick DG, Kindrachuk RW, Rouse RV. Prostatic adenocarcinoma with endometrioid features. Am J Surg Pathol 1985;9:595-609.

8 Epstein JI, Woodruff JM. Adenocarcinoma of the prostate with endometrioid features: a light microscopic and immunohistochemical study of 10 cases. Cancer 1986;57:111-119.

9 Ro JY, Ayala AG, Wishnow KI, et al. Prostatic ductal adenocarcinoma with endometrioid features: immunohistochemical and electron microscopic study. Semin Diagn Pathol 1988;5:301-311.

10 Christensen WN, Steinberg C, Walsh PC, et al. Prostatic duct adenocarcinoma: findings at radical prostatectomy. Cancer 1991;67:2118-2124.

11 Millar EKA, Sharma NK, Lessells AM. Ductal (endometrioid) adenocarcinoma of the prostate: a clinicopathologic study of 16 cases. Histopathology 1996;29:11-19.

12 Oxley JD, Abbot CD, Gillatt DA, et al. Ductal carcinomas of the prostate: a clinicopathological and immunohistochemical study. Br J Urol 1998;81: 109-115.

13 Bock BJ, Bostwick DG. Does prostatic ductal adenocarcinoma exist? Am J Surg Pathol 1999;23: 781-785.

14 Dawkins HJ, Sellner LN, Turbett GN, et al. Distinction between intraductal carcinoma of the prostate (IDCP), high grade dysplasia (PIN) and invasive prostatic adenocarcinoma, using molecular markers of cancer progression. Prostate 2000;44:265-270.

15 Humphrey PA. Variants of Prostatic Carcinoma in Prostate Pathology. ASCP Press: Chicago, IL, 2003.

16 Brinker DA, Potter SR, Epstein JI. Ductal adenocarcinoma of the prostate diagnosed on needle biopsy: correlation with clinical and radical prostatectomy findings and progression. Am J Surg Pathol 1999;23:1471-1479.

17 Gleason DF. Histologic grading of prostatic carcinomas. In: Bostwick DG (ed). Pathology of the Prostate. Churchill Livingstone: New York, NY, 1990.

18 Bostwick DG. Grading of prostate cancer. Am J Clin Pathol (Suppl) 1994;102:S38-S56.

19 Epstein JI, Yang XJ. Prostate Biopsy Interpretation. Lippincott, Williams \& Wilkins: Philadelphia, PA, 2002.

20 Samaratunga H, Mahendra S. Distribution pattern of basal cells detected by cytokeratin 34betaE12 in primary prostatic ductal adenocarcinoma. Am J Surg Pathol 1997;21:435-440.

21 Epstein JI, Lieberman PH. Mucinous adenocarcinoma of the prostate gland. Am J Surg Pathol 1985;9: 299-304.

22 Dhom G. Unusual prostatic carcinomas. Pathol Res Pract 1990;186:28-36.

23 Ro JY, Grignon DJ, Ayala AG, et al. Mucinous adenocarcinoma of the prostate: immunohistochemical studies. Hum Pathol 1990;21:593-600.

24 McNeal JE, Alroy J, Villers A, et al. Mucinous differentiation in prostatic adenocarcinoma. Hum Pathol 1991;22:979-988.

25 Teichman JMH, Shabaik A, Demby AM. Mucinous adenocarcinoma of the prostate and hormone sensitivity. J Urol 1994;151:701-702.

26 Saito S, Iwaki H. Mucin-producing carcinoma of the prostate: review of 88 cases. Urology 1999;54:141-144.

27 Ro JY, Grignon DJ, Troncoso P, et al. Mucin in prostatic adenocarcinoma. Semin Diagn Pathol 1988;5:273-283.

28 Saez C, Japon MA, Conde AF, et al. Sialomucins are characteristically $O$-acetylated in poorly differentiated and colloid prostatic adenocarcinoma. Mod Pathol 1998;11:1193-1197.

29 Van de Voorde W, Van Poppel HP, Haustermans K, et al. Mucin-secreting adenocarcinoma of the prostate with neuroendocrine differentiation and Paneth-like cells. Am J Surg Pathol 1994;18:200-207.

30 Tran TA, Jennings TA, Ross JS, et al. Pseudomyxoma ovariilike posttherapeutic alteration in prostatic adenocarcinoma: a distinctive pattern in patients receiving neoadjuvant androgen ablation therapy. Am J Surg Pathol 1998;22:347-354.

31 Giltman LI. Signet ring cell adenocarcinoma of the prostate. J Urol 1981;126:134-135.

32 Ro JY, El-Naggar A, Ayala AG, et al. Signet ring cell carcinoma of the prostate: electron-microscopic and immunohistochemical studies of eight cases. Am J Surg Pathol 1988;12:453-460. 
33 Hejka AG, England DM. Signet ring cell carcinoma of prostate: immunohistochemical and ultrastructural study of a case. Urology 1989;24:155-158.

34 Guerin D, Hasan N, Keen CE. Signet ring cell differentiation in adenocarcinoma of the prostate: a study of five cases. Histopathology 1993;22:367-371.

35 Smith C, Feddersen RM, Dressler L, et al. Signet ring cell adenocarcinoma of prostate. Urology 1994;43: 397-400.

36 Leong FJ, Leong AS, Swift J. Signet-ring carcinoma of the prostate. Pathol Res Pract 1996;192:1232-1238.

37 Torbenson M, Dhir R, Nangia A, et al. Prostatic carcinoma with signet ring cells: a clinicopathologic and immunohistochemical analysis of 12 cases, with review of the literature. Mod Pathol 1998;11:552-559.

38 Kuroda N, Yamasaki I, Nakayama H, et al. Prostatic signet-ring cell carcinoma: case report and literature review. Pathol Int 1999;49:457-461.

39 Schned AR. Artifactual signet-ring cells [letter]. Am J Surg Pathol 1987;11:736-737.

40 Alguacil-Garcia A. Artifactual changes mimicking signet ring cell carcinoma of transurethral prostatectomy specimens. Am J Surg Pathol 1986;10:795-800.

41 Mott LJM. Squamous cell carcinoma of the prostate: report of 2 cases and review of the literature. J Urol 1979;121:833-836.

42 Miller VA, Reuter V, Scher HI. Primary squamous cell carcinoma of the prostate after radiation and seed implantation for adenocarcinoma. Urology 1995;46:111-113.

43 Rahmanou F, Koo J, Marinbakh AY, et al. Squamous cell carcinoma at the prostatectomy site: squamous differentiation of recurrent prostate carcinoma. Urology 1999;54:744.

44 Okada E, Kamizaki H. Primary squamous cell carcinoma of the prostate. Int J Urol 2000;7:347-350.

45 Imamura M, Nishiyama $\mathrm{H}$, Ohmori $\mathrm{K}$, et al. Squamous cell carcinoma of the prostate without evidence of recurrence 5 years after operation. Urol Int 2000;65: $122-124$.

46 Nabi G, Ansari MS, Singh I, et al. Primary squamous cell carcinoma of the prostate: a rare clinicopathologic entity. Report of 2 cases and review of the literature. Urol Int 2001;66:216-219.

47 Majeed F, Javed TA, Khan AU, et al. Primary squamous cell carcinoma of the prostate: a novel chemotherapy regimen. J Urol 2002;168:640.

$48 \mathrm{Al}$ Adnani MS. Schistosomiasis, metaplasia and squamous cell carcinoma of the prostate: histogenesis of the squamous cancer cells determined by localization of specific markers. Neoplasma 1985;32:613-622.

49 Saito R, David BK, Ollipally EP. Adenosquamous carcinoma of the prostate. Hum Pathol 1984;15: 87-89.

50 Devaney DM, Dorman A, Leader M. Adenosquamous carcinoma of the prostate: a case report. Hum Pathol 2001;22:1046-1050.

51 Gattuso P, Carson HJ, Candel A, et al. Adenosquamous cell carcinoma of the prostate. Hum Pathol 1995;26:123-126.

52 Bassler. Jr TJ, Orozco R, Bassler IC, et al. Adenosquamous carcinoma of the prostate: case report with DNA analysis, immunohistochemistry and literature review. Urology 1999;53:832-834.

53 Frankel. Jr KC. Adenoid cystic carcinoma of the prostate: report of a case. Am J Clin Pathol 1974;62:639-645.
54 Gilmour AM, Bell TJ. Adenoid cystic carcinoma of the prostate. Br J Urol 1986;58:105-106.

55 Grignon DJ, Ro JY, Ordonez NG, et al. Basal cell hyperplasia, adenoid basal cell tumor and adenoid cystic carcinoma of the prostate gland: an immunohistochemical study. Hum Pathol 1988;19: 1425-1433.

56 Young RH, Frierson RH, Mills SE, et al. Adenoid cystic-like tumor of the prostate gland: a report of two cases and review of the literature on adenoid cystic carcinomas of the prostate. Am J Clin Pathol 1988;89:49-56.

57 Denholm SW, Webb JN, Howard GCW, et al. Basaloid carcinoma of the prostate gland: histogenesis and review of the literature. Histopathology 1992;20: 151-155.

58 Deveraj LT, Bostwick DG. Atypical basal cell hyperplasia of the prostate: immunophenotypic profile and proposed classification of basal cell proliferations. Am J Surg Pathol 1993;7:645-659.

59 Van Renterghem K, Mattelaer J, Billiet I. Adenoid cystic carcinoma of the prostate. Acta Urol Belg 1994;62:69-70.

60 Yang XJ, McEntee M, Epstein JI. Distinction of basaloid carcinoma of the prostate from benign basal cell lesions by immunohistochemistry for bcl-2 and Ki-67. Hum Pathol 1998;29:1447-1450.

61 Terris MK. The appearance of adenoid cystic carcinoma of the prostate on transrectal ultrasonography. BJU Int 1999;83:875-876.

62 Minei S, Hachiya T, Ishida $\mathrm{H}$, et al. Adenoid cystic carcinoma of the prostate: a case report with immunohistochemical and in situ hybridization staining for prostate-specific antigen. Int J Urol 2001;8: S41-S44.

63 Schmid HP, Semjenow A, Eltze E, et al. Late recurrence of adenoid cystic carcinoma of the prostate. Scand J Urol Nephrol 2002;36:158-159.

64 Young RH, Srigley JR, Amin MB. Variants of prostatic adenocarcinoma, other primary carcinomas of prostate and secondary carcinoma. In: Tumors of the Prostate Gland, Seminal Vesicles, Male Urethra and Penis. Armed Forces Institute of Pathology: Washington, DC, 2000, pp 217-255.

65 Wick MR, Young RH, Malvesta R, et al. Prostatic carcinosarcomas: clinical, histologic and immunohistochemical data on two cases with a review of the literature. Am J Clin Pathol 1989;92:131-139.

66 Shannon RL, Ro JY, Grignon DJ, et al. Sarcomatoid carcinoma of the prostate: a clinicopathologic study of 12 cases. Cancer 1992;69:2676-2682.

67 Lauwers GY, Schevchuk M, Armenakas N, et al. Carcinosarcoma of the prostate. Am J Surg Pathol 1993;7:342-349.

68 Dundore PA, Cheville JC, Nascimento AG, et al. Carcinosarcoma of the prostate: report of 22 cases. Cancer 1995;76:1035-1042.

69 Koleski FC, Turk TM, Wojcik EM, et al. Carcinosarcoma of the prostate. World J Urol 1999;17:316-318.

70 Delahunt B, Eble JN, Nacey JN, et al. Sarcomatoid carcinoma of the prostate: progression from adenocarcinoma is associated with p53 overexpression. Anticancer Res 1999;19:4279-4283.

71 Renshaw AA, Granter SR. Metastatic sarcomatoid, and PSA- and PAP-negative prostatic carcinoma: diagnosis by fine needle aspiration. Diagn Cytopathol 2000;23:199-201. 
72 Poblet E, Gomez-Tierno A, Alfaro L. Prostatic carcinosarcoma: a case originating in a previous ductal adenocarcinoma of the prostate. Pathol Res Pract 2000;196:569-572.

73 Canfield SE, Gans TH, Unger P, et al. Postradiation prostatic sarcoma: de novo carcinogenesis or dedifferentiation of prostatic adenocarcinoma? Tech Urol 2001;7:294-295.

74 Bostwick DG, Adlakha K. Lymphoepithelioma-like carcinoma of the prostate. J Urol Pathol 1994;12: 319-325.

75 Di Sant'Agnese PA. Divergent neuroendocrine differentiation in prostatic carcinoma. Semin Diagn Pathol 2000;17:149-161.

76 Adlakha K, Bostwick DG. Paneth cell-like change in prostatic adenocarcinoma represents neuroendocrine differentiation: report of 30 cases. Hum Pathol 1994;25:135-139.

77 Tetu B, Ro JY, Ayala AG, et al. Small cell carcinoma of prostate: a clinicopathologic study of 20 cases. Cancer 1987;59:1803-1809.

78 Moore SR, Reinberg Y, Zhang G. Small cell carcinoma of prostate: effectiveness of hormonal versus chemotherapy. Urology 1992;39:411-416.

79 Amato RJ, Logothetis CJ, Hallinan R, et al. Chemotherapy for small cell carcinoma of prostatic origin. J Urol 1992;147:935-937.

80 Oesterling JE, Hauzear CG, Farrow GM. Small cell anaplastic carcinoma of the prostate: a clinical, pathological and immunohistological study of 27 patients. J Urol 1992;147:804-809.

81 Rubenstein JH, Katin MJ, Mangano MM, et al. Small cell anaplastic carcinoma of the prostate: seven new cases, review of the literature, and discussion of a therapeutic strategy. Am J Clin Oncol 1997;20: 376-380.

82 Mackey JR, Au HJ, Hugh J, et al. Genitourinary small cell carcinoma: determination of clinical therapeutic factors associated with survival. J Urol 1998;159: 1624-1629.

83 Schwartz LH, LaTrenta LR, Bonaccio E, et al. Small cell and anaplastic prostate cancer: correlation between CT findings and prostate-specific antigen level. Radiology 1998;208:735-738.

84 Helpap B, Kollerman J. Undifferentiated carcinoma of the prostate with small cell features: immunohistochemical subtyping and reflections on histogenesis. Virchows Arch 1999;434:385-391.

85 Tanaka M, Suzuki Y, Takaoka K, et al. Progression of prostate cancer to neuroendocrine cell tumor. Int J Urol 2001;8:431-436.

86 Lopez Cubillana P, Martinez Barba E, Prieto A, et al. Oat-cell carcinoma of the prostate: diagnosis, prognosis and therapeutic implications. Urol Int 2001;67: 209-212.

87 Papandreou CN, Daliana DD, Thall PF, et al. Results of a phase II study with doxorubicin, etoposide, and cisplatin in patients with fully characterized smallcell carcinoma of the prostate. J Clin Oncol 2002;20:3072-3080.

88 Ro JY, Tetu B, Ayala AG, et al. Small cell carcinoma of the prostate: immunohistochemical and electron microscopic studies of 18 cases. Cancer 1987;59: 1803-1809.

89 Greene LF, O’Dea MF, Dockerty MB. Primary transitional cell carcinoma of the prostate. J Urol 1976;116: 235-237.
90 Johnson DE, Hogan JM, Ayala AG. Transitional cell carcinoma of the prostate. Cancer 1972;29:287-293.

91 Greene LF, Mulcashy JJ, Warren MM, et al. Primary transitional cell carcinoma of the prostate. J Urol 1973;110:235-237.

92 Mahadevia PS, Koss LG, Tar IJ. Prostatic involvement in bladder cancer: prostate mapping in 20 cystoprostatectomy specimens. Cancer 1986;58:2095-2102.

93 Nixon RG, Chang SS, Lafleur BJ, et al. Carcinoma in situ and tumor multifocality predict the risk of prostatic urethral involvement at radical cystectomy in men with transitional cell carcinoma of the bladder. J Urol 2002;167:502-505.

94 Wood. Jr DP, Montie JE, Pontes JE, et al. Transitional cell carcinoma of the prostate in cystoprostatectomy specimens removed for bladder cancer. J Urol 1989;141:346-349.

95 Ende N, Woods LP, Shelley HS. Carcinoma originating in ducts surrounding the prostatic urethra. Am J Clin Pathol 1963;40:183-189.

96 Karpas CM, Moumgis B. Primary transitional cell carcinoma of the prostate: possible pathogenesis and relationship to reserve cell hyperplasia of prostatic periurethral ducts. J Urol 1969;101:201-205.

97 Ullmann AS, Ross OA. Hyperplasia, atypism and carcinoma in situ in prostatic periurethral glands. Am J Clin Pathol 1967;747:497-504.

98 Razvi M, Fifer R, Berkson B. Occult transitional cell carcinoma of the prostate presenting as skin metastases. J Urol 1975;113:734-735.

99 Oliai BR, Kahane H, Epstein JI. A clinicopathologic analysis of urothelial carcinomas diagnosed on prostate needle biopsies. Am J Surg Pathol 2001;25:794-801.

100 Sawczuk I, Tannenbaum M, Olson CA, et al. Primary transitional cell carcinoma of prostate periurethral ducts. Urol 1985;25:339-343.

101 Takashi MS, Sakata T, Nagai T, et al. Primary transitional cell carcinoma of prostate: case with lymph node metastasis eradicated by neoadjuvant methotrexate, vinblastine, doxorubicin, and cisplatin (M-vac) therapy. Urology 1990;36:96-98.

102 AJCC. AJCC Cancer Staging Manual, 6th edn, Springer: New York, 2002.

103 Cheville JC, Dundore PA, Bostwick DG, et al. Transitional cell carcinoma of the prostate: clinicopathologic study of 50 cases. Cancer 1998;82: 703-707.

104 Nicolaisen GS, Williams RD. Primary transitional cell carcinoma of the prostate. Urology 1984;24:544-549.

105 Smith BD, Flegel G. Primary transitional cell carcinoma of the prostate: report of two cases. J Am Osteopath 1982;82:547-548.

106 Tannenbaum M. Transitional cell carcinoma of the prostate. Urology 1975;5:674-678.

107 Goebbels R, Amberger L, Wernert N, et al. Urothelial carcinoma of the prostate. Appl Pathol 1985;3: 242-254.

108 Cheville JC. Urothelial carcinoma of the prostate: an immunohistochemical comparison with high grade prostatic adenocarcinoma and review of the literature. J Urol Pathol 1998;9:141-154.

109 Bodner DR, Cohen JK, Resnick MI. Primary transitional cell carcinoma of the prostate. J Urol 1986;92:121-122.

110 Laplante M, Brice M. The upper limits of hopeful application of radical cystectomy for vesical carcinoma: does nodal metastasis always indicate incurability? J Urol 1973;109:261-264. 